\title{
VARIASI VOKAL BAHASA MELAYU DI RIAU DARATAN DAN RIAU KEPULAUAN
}

\section{(VOWEL VARIATION OF MALAY LANGUAGE IN THE LAND OF RIAU AND THE ISLANDS OF RIAU)}

\author{
Hidayatul Astar \\ Kantor Bahasa Provinsi Bengkulu \\ Jalan K.S.Tubun Blok G Nomor 9, Gading Cempaka \\ Lingkar Barat, Bengkulu 38225 \\ Posel:hidayatul.astar@yahoo.co.id
}

\begin{abstract}
This article is a study of vowel variation of Malay language in the land of Riau and the Islands of Riau. This is a comparative study which aims to compare given vowels in an etymon on the first and the second syllable of Malay language in two regions. The results show that Malay vowels in the Island of Riau are more varied than in the Land of Riau: 63\% on the second syllable; $37 \%$ on the first syllable. Vocals on the second syllable of the islands of Riau and the land of Riau are more than the first vocals. Vocals on the first syllable are $[a],[\dot{U}],[u],[o]$, and $[i]$, while the second syllables are $[a] ;[o],[e] ;[\dot{U}],[]],\left[i^{y} a\right],[i],[u]$, and $\left[u^{w} a\right]$. As Riau islands has more vocal variations, this region is considered as the center of vocal innovation.
\end{abstract}

Key Word: Malay language, vowel variation, first syllable, second syllable, center of innovation.

\begin{abstract}
Abstrak
Artikel ini merupakan hasil kajian terhadap variasi vokal bahasa Melayu di Riau Daratan dan Riau Kepulauan. Kajian ini bersifat komparatif yang bertujuan membandingkan vokal berian dalam satu etimon, sebuah glos pada suku pertama dan kedua pada bahasa Melayu di dua wilayah tersebut. Hasil kajian ini membuktikan bahwa vokal bahasa Melayu di Riau Kepulauan lebih variatif daripada di Riau Daratan: 63\% pada suku kata kedua; 37\% pada suku kata pertama. Vokal pada suku kata kedua bahasa Melayu di Riau Kepulaun dan Riau Daratan lebih banyak daripada vokal pada suku kata pertama. Vokal pada suku kata pertama adalah [a],[ə], [u], [o], dan [i], sedangkan pada suku kedua adalah [a]; [o], [e]; [ə], [], [i $\left.{ }^{\mathrm{y} a}\right],[\mathrm{i}],[\mathrm{u}]$, dan [ [ ${ }^{\mathrm{w} a}$ ]. Karena variasi vokal di Riau Kepulauan lebih banyak, wilayah itu dianggap pusat inovatif vokal.
\end{abstract}

Kata Kunci: Bahasa Melayu, variasi vokal, suku pertama, suku kedua, pusat inovatif 


\section{Pendahuluan}

Salah satu dari tiga belas bahasa regional utama di Indonesia atau yang berpenutur lebih dari satu juta orang adalah bahasa Melayu (Lauder dan Ayatrohaedi, 2005: 1). Bahasa itu dituturkan oleh penduduk di beberapa wilayah di Indonesia: Sumatera, Jawa, Kalimantan, Sulawesi, Maluku, dam Papua. Khusus diwilayah Sumatera, bahasa Melayu dituturkan oleh penduduk, terutama yang berada di pantai timur dan tenggara Sumatera (Hatori, 1981). Menurut SIL (2001), penutur bahasa Melayu sekitar 20 juta orang dan setengahnya berada di wilayah Sumatera. Dengan jumlah penutur seperti itu, bahasa Melayu tidak termasuk dalam dua puluh bahasa utama di dunia yang berpenutur 50 juta atau lebih. Sebenarnya menurut Collins (dalam Lauder dan Ayatrohaedi 2005: 4), bahasa Melayu itu termasuk salah satu dari lima bahasa terbesar di dunia. Pendapatnya didasari oleh kenyataan bahwa bahasa Melayu itu memiliki variasi nama, seperti bahasa Indonesia, bahasa Malaysia, bahasa Brunai, bahasa Ancalong Kutai, bahasa Bacan, dan bahasa Ulu.

Kajian terhadap bahasa Melayu di wilayah Indonesia cukup banyak dilakukan oleh linguis. Kajian yang mereka lakukan mencakupi bidang fonologi, morfologi, sintaksis, dan semantik. Kajian yang terkait dengan penelitian ini adalah kajian yang dilakukan oleh Nothofer (1975; 1988; 1995), Blust (1981; 1988), Collins (1986; 1995), Adelaar (1994). Nothofer $(1975 / 1988)$ telah merekonstruksi bahasa Melayu-Jawa dan melihat perubahan bunyi dan inovasi (inovasi fonologis, morfologis, leksikal, dan semantik) yang terjadi(1995) dalam bahasa Melayu di Kalimantan dan Sumatera bagian tenggara (Bangka, Belitung, dan Pelembang). Hal yang sama juga dilakukan oleh Collins (1986: 87-133); 1995: 5374) ketika dia meneliti bahasa di Melayu Ambon dan dan Bacan. Dia mengkaji bahasa Melayu Ambon yang terkait dengan bidang fonologi, leksikon, sedikit mengenai rekonstruksi, dan inovasi. Sementara itu, Blust (1981:140 - 218) juga mengkaji masalah rekonstruksi bahasa Melayu-Jawa Purba dan fonologi bahasa Melayu. Dia juga (1988: 140-218) menghitung tingkat kekerabatan beberapa bahasa Melayu yang terdapat di Sumatera, Jawa, dan Kali- mantan. Agak bebeda dengan ketiga linguis itu, Adelaar (1994)lebih menfokuskan diri pada kajian rekonstruksi, yaitu rekonstruksi fonologi dan sedikit morfologi dan leksikon. Keempat peneliti itu dalam analisisnya menggunakan prinsip-prinsip linguistik historis komparatif, yaitu yang berkaitan dengan perubahan bunyi yang terjadi pada bahasa yang mereka perbandingkan. Di samping keempat linguis itu, linguis lain yang mengkaji bahasa Melayu adalah Tadmor (2000) dan Oglobin (2000). Uri lebih mengkaji aksen bahasa melayu, sedangkan Oglobin mengkaji evolusi bahasa Melayu.

Kajian terhadap bahasa Melayu Riau telah dilakukan oleh Dahlan. Dia lebih banyak meneliti dalam bidang dialektologi dan sedikit menyingung masalah linguistik historis komparatif. Dia telah melakukan penelitian di daerah Kampar bagian timur (1976), di daerah bekas Kerajaan Siak (1977), di daerah Riau Kepulauan (1989). Dalam bidang linguistik histors komparatif, telah dia lakukan perhitungan secara leksikostatistik untuk menentukan tingkat kekerabatan bahasa Melayu wilayah Riau itu. Pedoman yang digunakannya dalammenghitung itu adalah kata yang identik, mirip, dan beda. Apa yang telah dia lakukan itu belum memadai karena tidak dilanjutkan dengan analisis yang lebih mendalam terhadap adanya perbedaan-perbedaan leksikon dan bunyi dalam bahasa Melayu itu dalam kaitannya dengan bentuk protobahasa dan hubungannya dengan bahasa lain seperti kajian yang dilakukan oleh Lauder (1990) dan (Mahsun 1995). Misalnya mengacu ke bentuk proto yang direkonstruksi oleh Dempwolff(1938) atau melihat inovasi yang terjadi. Dia juga tidak menentukan mana daerah yang inovatif dan mana daerah yang konservatif.

Dalam kajian linguistik historis terdapat beberapa pokok bahasan yang berkaitan dengan apa yang diteliti oleh para linguis. Yang sering dilakukan adalah melihat perubahan yang terjadi dalam bahasa seperti yang telah dilakukan empat linguis yang telah disebutkan di atas dan juga yang dilakukan Oleh Fernadez (1996). Perubahan yang terjadi kadang-kadang tidak terasa setiap waktu (Robins 1989/1992: 417). Perubahan itu dapat berupa perubahan secara fonologis, morfologis, sintaksis, dan semantik. Sehubungan 
dengan itu, dalam penelitian ini dimanfaatkan kerangka berpikir yang terkait dengan perubahan bahasa itu, khususnya perubahan bunyi. Beberapa prinsip perubahan bunyi atau bentuk telah dikemukan, antara lain, oleh Lehman (1973), Hock (1986), Crowly (1987), dan Schendel (2001). Perubahan bunyi itu dapat dibagi dua, yaitu perubahan bunyi yang teratur yang disebut dengan korespondensi dan perubahan bunyi yang tidak teratur yang disebut dengan variasi(Mahsun 1995: 30). Perubahan bunyi yang mereka kemukakan pada prinsipnya sama saja. Yang membedakan jenis perubahan bunyi yang mereka bahas.

Kajian terhadap perubahan bunyi boleh dikatakan kajian yang dominan dilakukan oleh para peneliti bahasa Melayu seperti yang ditunjukkan oleh empat linguis, Nothofer, Blust, Collins, dan Adelar. Oleh karena itu, apa yang mereka lakukan akan menjadi kerangka kerja yang akan digunakan dalam penelitian ini. Sehubungan dengan itu, berbagai bentuk perubahan bunyi, antara lain, asimilasi, disimilasi, metatesis, kontraksi, aferesis, sinkope, apokope, protesis, epentesis, dan paragog akan menjadi acuan analisis data.

Terkait dengan itu, tulisan ini mengungkapkan variasi vokal yang terdapat di wilayah Riau Daratan (RD) dan Riau Kepulauan (RK). Selanjutnya, vokal di wilyah Riau mana yang lebih variatif adalah inti dari yang ingin diungkap dalam tulisan ini. Sumber data yang akan digunakan dalam penelitian ini adalah yang terdapat dalam kuesioner hasil pengumpulan data lapangan yang telah dilakukan oleh Tim Pemetaan Pusat Bahasa tahun 1996 pada 18 daerah (titik pengamatan), yaitu (1) Bangkinang, (2) Bonai, (3) Pedalian, (4) Pulau Godang, (5) Sukadamai, (6) Pelitung, (7) Pangkalan Indarung, (8) Sukaping, (9) Air Balui, (10) Pecong, (11) Arung Ayam, (12) Ceruk, (13) Dundur, (14) Mantang Lama, (15) Merawang, (16) Pulau Laut, (17) Karas, dan (18) Sedanau Timur. Desa (1) - (5) berada di Kabupaten Kampar, (6) di Kabupaten Bengkalis, (7) dan (8) di Kabupaten Indragiri Hulu, (9) di Kabupaten Indragiri Hilir, (10) - (18) di Riau Kepulauan. Realisasi vokal itu dibatasi pada berian satu etimon saja pada suku kata pertama dan kedua.

\section{Pembahasan}

Berdasar data, realisasi vokal bahasa Melayu pada suku kata kedua lebih variatif(lebih banyak) daripada pada suku kata pertama. Dari 106 glos yang memiliki perbedaan realisi vokal, 67 glos atau $63 \%$ memperlihatkan perbedaan realisasi vokal pada suku kata kedua dan 39 glos atau 37\% memperlihatkan perbedaan realisasi vokal pada suku kata pertama.

\subsection{Variasi Vokal pada Suku Kata Pertama}

Berdasarkan berian glos yang diteliti, variasi vokal pada suku kata pertama dapat dua, tiga, atau lebih. Data (1) - (4) mempelihatkan dua variasi vokal, sedangkan data (5) - (11) memperlihatkan tiga variasi vokal.

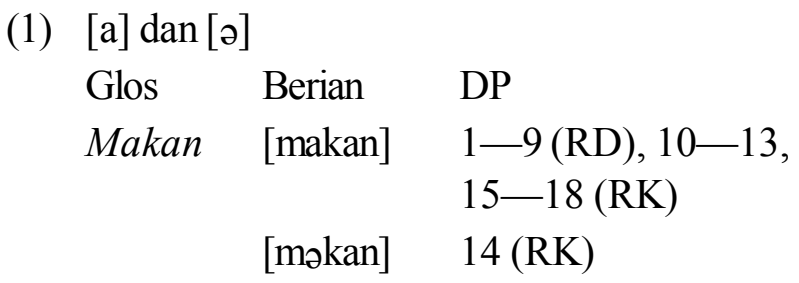

Vokal [a] terdapat pada semua DP di RD dan pada DP 10 - 13 dan 15-18 di RK; [Ü] hanya terdapat di RKDP 14. Data itu mengidikasikan bahwa vokal di RK lebih variatif daripada di RD. Terlihat pula dalam data (2) berikut bahwa vokal bahasa Melayu di RK lebih variatif daripada di RD.

(2) $[\mathrm{u}] \operatorname{dan}[\mathrm{o}]$

$\begin{array}{lll}\text { Glos } & \text { Berian } & \text { DP } \\ \text { Buah } & {\left[\mathrm{bu}^{\mathrm{w} a}\right]} & 1-3,7,8(\mathrm{RD}) \\ & {\left[\mathrm{bu}^{\mathrm{w} a h}\right]} & 4,6,9(\mathrm{RD}), \\ & & 12,13,14,16(\mathrm{RK}) \\ & {\left[\mathrm{bu}^{\mathrm{w}} \mathrm{oh}\right]} & 10,18(\mathrm{RK}) \\ & {\left[\mathrm{bo}^{\mathrm{w}} \mathrm{ah}\right]} & 11(\mathrm{RK}) \\ & {\left[\mathrm{bu}^{\mathrm{w}} \mathrm{eh}\right]} & 15,17(\mathrm{RK})\end{array}$

Vokal $[\mathrm{u}]$ terdapat pada semua DP yang terdapat di RD dan pada DP 10, 12-18 di RK. Sementara vokal [o] haya terdapat di RK DP 11. Jadi, ada satu vokal di RD dan dua vokal di RK.

Data (3) berikut menggambarkan bahwa vokal bahasa Melayu di RD lebih variatif dariapada di RK.

(3) [i] dan [u]

$\begin{array}{lll}\text { Glos } & \text { Berian } & \text { DP } \\ \text { Kulit } & \text { [kilik] } & 1,2,5,7(\mathrm{RD})\end{array}$




$\begin{array}{ll}\text { [kulit ] } & 6(\mathrm{RD}), 10,11,13, \\ & 15-18(\mathrm{RK}) \\ \text { [kulet] } & 12,14(\mathrm{RK}) \\ \text { [kulè̀ }] & 3(\mathrm{RD})\end{array}$

Vokal [u] terdapat pada semua DP yang terdapat di RK dan pada DP 3, dan 6 di RD. Sementara vokal [i] terdapat di RD DP 1,2,5, dan 7. Jadi, ada satu vokal di RK dan dua vokal di RD. Fakta itu didukung pulang oleh data (4) berikut.

(4) $[0]$ dan [ə]

$\begin{array}{lll}\text { Glos } & \text { Berian } & \mathrm{DP} \\ \text { Besar } & {[\text { bosa }]} & 2(\mathrm{RD}) \\ & {[\text { bəsə }]} & 5(\mathrm{RD}), 10,14,17(\mathrm{RK}) \\ & {[\text { bəso }]} & 12,18(\mathrm{RK}) \\ & {[\text { bəsa }]} & 13(\mathrm{RK}) \\ & {[\text { bəsoh }]} & 16(\mathrm{RK}) \\ & {[\text { bəsaÀ }]} & 15(\mathrm{RK}) \\ & {[\text { bosaR }]} & 4(\mathrm{RD}) \\ & {[\text { bəsar }]} & 11(\mathrm{RK})\end{array}$

Vokal [ə] terdapat pada semua DP yang terdapat di RK dan pada DP 5 di RD. Sementara itu, vokal [o] terdapat pada DP 2 dan 4 di RD.

Dari data (1) - (4) dapat diketahui bahwa vokal bahasa Melayu di RK dan RD memiliki tingkat kevariatif vokal yang sama. Vokal di RK pada suku pertama empat, yaitu [a],[ə], [u], dan [o], dan di RD juga empat, yaitu [a], [u], [o], dan [i].

Data (5) berikut memperlihatkan vokal di RK lebih variatif dariapada vokal di RD.

(5) $[\mathrm{a}],[\mathrm{\jmath}],[\mathrm{o}]$

$\begin{array}{lll}\text { Glos } & \text { Berian } & \text { DP } \\ \text { Basah } & {[\text { baseh }]} & 15(\mathrm{RK}) \\ & {[\text { baseh }]} & 6,9(\mathrm{RD}), 13,16,18(\mathrm{RK}) \\ & {[\text { basa }]} & 1,8(\mathrm{RD}) \\ & {[\text { bosah }]} & 10,12,14,17(\mathrm{RK}) \\ & {[\text { bosah }]} & 11(\mathrm{RK})\end{array}$

Vokal [a] terdapat pada semua DP di RD dan pada DP 13, 16, dan 18 di RK; [ə] hanya terdapat di RK DP 10,12,14, dan 17; [o] hanya terdapat di RK DP 2. Fakta seperti itu terlihat pula pada data (6), (7), dan (8) berikut.

Gramatika, Volume I, Nomor 2, Juli-Desember 2013
(6) [a], [ə], [o]

$\begin{array}{lll}\text { Glos } & \text { Berian } & \text { DP } \\ \text { Danau } & {[\text { danaw }]} & 1-6,8,9(\mathrm{RD}), \\ & & 15-18(\mathrm{RK}) \\ & {[\text { dənaw }]} & 10(\mathrm{RK}) \\ & {[\text { donaw }]} & 11(\mathrm{RK})\end{array}$

(7) $[\mathrm{a}],[\mathrm{]}],[\mathrm{o}]$

Glos Berian DP

Daun [daw $\quad 1,3-9(\mathrm{RD}), 12,13$, $15,16(\mathrm{RK})$

[da ${ }^{\mathrm{w}} \mathrm{on}$ 2(RD)

[dəw $10,17(\mathrm{RK})$

[down] 11, $18(\mathrm{RK})$

(8) [a], [ə], [o]

$\begin{array}{lll}\text { Glos } & \text { Berian } & \mathrm{DP} \\ \text { Bakar } & {[\text { bokar }]} & 11(\mathrm{RK}) \\ & {[\text { bakar }]} & 4,8,9(\mathrm{RD}), 16(\mathrm{RK}) \\ & {[\text { baka }]} & 2,3,5(\mathrm{RD}), 13(\mathrm{RK}) \\ & {[\text { bako] }} & 6(\mathrm{RD}) \\ & {[\text { bəka }]} & 10,12,17(\mathrm{RK}) \\ & {[\text { bəkə] }} & 14(\mathrm{RK}) \\ & {[\text { boka }]} & 18(\mathrm{RK})\end{array}$

Vokal [a] terdapat pada semua DP yang terdapat di RD dan pada DP 15-18 di RK glos danau dan DP 12,13,15, dan 16 pada glos daun. Vokal [ə] terdapat di RK DP 10 glos danau, DP 10 dan 17 glos daun, dan DP 13 dan 16 pada glos bakar. Sementara itu, [o] hanya terdapat pada DP 11 dan 18 di RK.

Data (9) berikut juga memperlihatkan bahwa vokal di RK lebih variatif daripada vokal di RD.
(9) [a], [o], dan [ə]
Glos Berian DP
Datang [dataž] 3,4,6-9(RD)
[dətaž] 10,14, $17(\mathrm{RD})$
[dotaž] 11, $18(\mathrm{RK})$

Vokal [a] terdapat pada semua DP yang terdapat di RD; vokal [ə] terdapat di RK DP 10, 14, dan 17; [o] terdapat pada DP 11 dan 18 di RK.

Dalam dua data (10) dan (11) berikut, terlihat vokal di RD lebih variatif daripada vokal di RK. 
(10) [ə], [e], dan [o]

Glos Berian DP

Kecil [kədik] $13(\mathrm{RK})$

[kəcit ] 15 (RK)

[kəciÀ ] 9 (RD),

$10,14,16,17,18(\mathrm{RK})$

[kəcIÀ] $11(\mathrm{RK})$

[keciÀ] $1(\mathrm{RD})$

[kociÀ ] $2(\mathrm{RD})$

[kocit] 6(RD)

[kociyè̀ ] 3, 4, 5 (RD)

[koci'ak] $7(\mathrm{RD})$

(11) $[$ ə], [e], dan [o]

\begin{tabular}{|c|c|c|}
\hline \multirow{12}{*}{$\begin{array}{l}\text { Glos } \\
\text { benar }\end{array}$} & Berian & DP \\
\hline & [bonail] & $7(\mathrm{RD})$ \\
\hline & [bona] & $2,5(\mathrm{RD})$ \\
\hline & [bonar ] & 4,8 (RD) \\
\hline & [benaR] & $9(\mathrm{RD})$ \\
\hline & [bəne] & 17 (RK) \\
\hline & [bənəR] & $16(\mathrm{RK})$ \\
\hline & [bənar] & 15 (RK) \\
\hline & [bənor] & $11(\mathrm{RK})$ \\
\hline & [bənoÀ] & $18(\mathrm{RK})$ \\
\hline & [bənəÀ] & 10 (RK) \\
\hline & [bəna] & 13 (RK) \\
\hline
\end{tabular}

Pada glos kecil, vokal [ə] terdapat pada semua DP yang terdapat di RK dan tidak ada di RD; [e] terdapat di RD, yaitu pada DP 1 glos kecil dan DP 9 glos benar. Sementara itu, [o] terdapat di RD DP 2-7 RD glos kecil dan DP 2,4,5, dan 7 glos benar.

Dari data (5) - (11) dapat diketahui bahwa vokal bahasa Melayu di RK dan di RD sama banyak, yaitu lima: [a], [ə], [u], [o], dan [i]. Walaupun sama banyak, pada glos tertentu ada kecenderungan vokal di RK lebih variatif(lebih banyak) daripada vokal di RD.

\subsection{Variasi Vokal pada Suku Kata Kedua}

Variasi vokal pada suku kata dapat dua variasi, tiga variasi, atau lebih. Data dua variasi terlihat dalam data (12)-(16) berikut.
(12) $[\mathrm{a}]$ dan [ə]

$\begin{array}{lll}\text { Glos } & \text { Berian } & \mathrm{DP} \\ \text { bintang } & \text { [bintaž] } & 1-9(\mathrm{RD}), \\ & & 11-15,18(\mathrm{RK}) \\ & \text { [bintəž }] & 10,17(\mathrm{RK}) \\ & \text { [bindaž }] & 16(\mathrm{RK})\end{array}$

Vokal [a] glos bintang terdapat pada semua DP yang terdapat di RD dan pada DP $11-16$ dan 18 di RK; [ə] terdapat pada DP 10 dan 17 di RK. Data itu mengindikasikan bahwa vokal di RK lebih variatif dari vokal RD. Fakta itu didukung pula oleh data (13) berikut.

(13) [a] dan [o]

$\begin{array}{lll}\text { Glos } & \text { Berian } & \text { DP } \\ \text { hijau } & \text { [hijaw }] & 4(\mathrm{RD}) \\ & \text { [ijaw }] & 1,2,3,5-9(\mathrm{RD}), \\ & & 10-16,18 \mathrm{RK}) \\ & \text { [ijow }] & 17(\mathrm{RK})\end{array}$

Vokal [a] terdapat pada semua DP di RD dan pada DP 11-16, 18, dan 19 di RK. Vokal [ə] terdapat pada DP 10 dan 17 di RK.

Dalam data (14) berikut, vokal di RD lebih variatif daripada di RK karena ada satu DP di RD, yaitu DP 2 yang merealisasikan vokal [o]. Sementara itu, vokal $[\mathrm{u}]$ terdapat pada semua DP di RK dan pada DP 1, 3-9 di RD

(14) $[\mathrm{u}] \operatorname{dan}[\mathrm{o}]$

$\begin{array}{lll}\text { Glos } & \text { Berian } & \text { DP } \\ \text { Daun } & {\left[\mathrm{da}^{\mathrm{w}} \mathrm{un}\right]} & 1,3-9(\mathrm{RD}), \\ & & 12,13,15,16(\mathrm{RK}) \\ & {\left[\mathrm{da}^{\mathrm{w}} \mathrm{on}\right]} & 2(\mathrm{RD}) \\ & {\left[\mathrm{d}^{\mathrm{w}} \mathrm{un}\right]} & 10,17(\mathrm{RK}) \\ & {\left[\mathrm{do}^{\mathrm{w}} \mathrm{un}\right]} & 11,18(\mathrm{RK})\end{array}$

Data (15) berikut menggambarkan bahwa vokal bahasa Melayu di RD dan RK sama variatif.

(15) [i] dan [e]

$\begin{array}{lll}\text { Glos } & \text { Berian } & \text { DP } \\ \text { kulit } & {[\text { kilik }]} & 1,2,5,7(\mathrm{RD}) \\ & {[\text { kulit }]} & 6(\mathrm{RD}), 10,11,13, \\ & & 15-18(\mathrm{RK}) \\ & {[\text { kulet }]} & 12,14(\mathrm{RK}) \\ & {[\text { kuleÀ }]} & 3(\mathrm{RD})\end{array}$


Vokal [i] terdapat di RD DP 1, 2, 5, 6, dan 7 dan di RK DP10-18); [e] terdapat di RD DP 3 dan di RK DP 12 dan 14. Data (16) berikut juga menggambarkan demikian.

(16) [a] dan [e]

$\begin{array}{lll}\text { Glos } & \text { Berian } & \text { DP } \\ \text { basah } & \text { [bəsah] } & 10,12,14,17(\mathrm{RK}) \\ & {[\text { bosah }]} & 11(\mathrm{RK}) \\ & {[\text { baseh }]} & 15(\mathrm{RK}) \\ & {[\text { baseh }]} & 6,9(\mathrm{RD}), 13,16, \\ & & 18(\mathrm{RK}) \\ & \text { [basa }] & 1,8(\mathrm{RD})\end{array}$

Vokal [a] terdapat di RD DP 1 dan 8 di RK DP1018; [e] terdapat di RD DP 6 dan 9 di RK DP 12 dan 14.

Dari data (12) — (16) diketahui bahwa ada enam vokal di RK, yaitu [a], [e], [o], [u], [i], dan [ə], sedangkan di RD lima, yaitu [a], [e], [o], [u], dan [i]. Data itu mengindikasikan vokal di RK lebih variatif daripada vokal di RD.

Data (17) - (26) berikut meperlihatkan variasi tiga vokal.

(17) [a], [o], dan [e]

$\begin{array}{lll}\text { Glos } & \text { Berian } & \text { DP } \\ \text { Buah } & {\left[\mathrm{bu}^{\mathrm{w} a}\right]} & 1-3,7,8(\mathrm{RD}) \\ & {\left[\mathrm{bu}^{\mathrm{w}} \mathrm{ah}\right]} & 4,6,9(\mathrm{RD}), \\ & & 1213,14,16(\mathrm{RK}) \\ & {\left[\mathrm{bu}^{\mathrm{w}} \mathrm{oh}\right]} & 10,18(\mathrm{RK}) \\ & {\left[\mathrm{bo}^{\mathrm{w}} \mathrm{ah}\right]} & 11(\mathrm{RK}) \\ & {\left[\mathrm{bu}^{\mathrm{w}} \mathrm{eh}\right]} & 15,17(\mathrm{RK})\end{array}$

Vokal [a] terdapat di semua DP RD dan DP 1114, 16 di RK DP10 - 18; [e] terdapat di RK DP 15 dan 17; [o] terdapat di RK DP 10 dan 18. Vokal di RK lebih variatif karena lebih banyak daripada di RD. Ada tiga vokal di RK dan satu vokal di RD. Data (18) juga mendukung kevariatifan vokal di RK. (18) [a], [o], dan [e]

$\begin{array}{lll}\begin{array}{l}\text { Glos } \\ \text { bulan }\end{array} & \text { Berian } & \text { DP } \\ & \text { [bulan] } & 1-9(\mathrm{RD}) \\ & & 13-16(\mathrm{RK}) \\ & \text { [bulon] } & 11,18(\mathrm{RK}) \\ & {[\text { bulen }]} & 12,17(\mathrm{RK})\end{array}$

Vokal [a] terdapat dalam semua DP di RD dan DP 13-16 di RK; Vokal [e] terdapat pada DP 12 dan 17 RK; vokal [o] terdapat pada DP 11 dan18 di RK. Data variasi (19) dan (20) berikut juga menggambarkan hal yang sama.

(19) [ə], [], dan [o]

$\begin{array}{lll}\text { Glos } & \text { Berian } & \mathrm{DP} \\ \text { tiga } & \text { [tigə?] } & 17(\mathrm{RK}) \\ & {[\text { tig] }} & 10,13,15(\mathrm{RK}) \\ & \text { [tigo] } & 1,2,5,7,8,9(\mathrm{RD}) \\ & \text { [tigə] } & 11,12,14,16,18(\mathrm{RK})\end{array}$

(20) [ə], [], dan [o]

$\begin{array}{lll}\text { Glos } & \text { Berian } & \text { DP } \\ \text { Kita } & {[\text { kito }]} & 2,3,4,6,5,7,9 \text { (RD) } \\ & \text { [kitə] } & 14,16,17(\mathrm{RK}) \\ & {[\text { kit }]} & 13(\mathrm{RK})\end{array}$

Vokal [ə] terdapat di RK DP 11, 12, 14, 16-18 glos tiga dan DP 14, 16, dan 17 glos kita; [] juga hanya terdapat pada di RK DP 10, 13, dan 15 glos tiga dan DP 13 glos kita); [o] hanya terdapat di RD saja.

Data (21) berikut juga mendukung bahwa vokal bahasa Melayu di RK juga lebih variatif daripada vokal di RD. Ada dua vokal di RD dan tiga vokal di RK.

\begin{tabular}{|c|c|c|}
\hline \multicolumn{3}{|c|}{ 1) $[\mathrm{a}],[\mathrm{o}]$, dan $[\partial]$} \\
\hline Glos & Berian & DP \\
\hline Besar & [bosa] & $2(\mathrm{RD})$ \\
\hline & [bəsə] & $5(\mathrm{RD}), 10,14,17(\mathrm{RK})$ \\
\hline & [bəso] & $12,18(\mathrm{RK})$ \\
\hline & [bəsa] & $13(\mathrm{RK})$ \\
\hline & [bəsoh] & $16(\mathrm{RK})$ \\
\hline & [bəsaÀ] & $15(\mathrm{RK})$ \\
\hline & [bosaR] & $4(\mathrm{RD})$ \\
\hline & [bəsar] & $11(\mathrm{RK})$ \\
\hline
\end{tabular}

Vokal [a] terdapat di DP2 dan 4 di RD dan DP 11, 13, dan15 di RK; Vokal [ə] terdapat pada DP 5 di RD dan DP10, 14 dan 17 di RK; [o] terdapat pada DP 12, 16, dan di RK.

Satu vokal di RD dan tiga vokal di RK diperlihatkan pula oleh data berikut. 
(22) [a], [o], dan [ə]

\begin{tabular}{|c|c|c|}
\hline Glos & Berian & DP \\
\hline apa & [apo] & $\begin{array}{l}1-9(\mathrm{RD}) 12,13,16, \\
\text { dan } 18(\mathrm{RK})\end{array}$ \\
\hline & [apa] & $15(\mathrm{RK})$ \\
\hline & [apaÀ] & $10,17(\mathrm{RK})$ \\
\hline & [арә] & $11,14(\mathrm{RK})$ \\
\hline
\end{tabular}

Vokal [a] terdapat dalam semua DP10,15, dan 17 di RK; Vokal [ə] terdapat pada DP 12 dan 17 di RK; vokal [o] terdapat pada semua DP di RD dan12, 13, 16, dan 18 di RK.

Realisasi vokal dalam data berikut memperlihatkan bahwa vokal di RD dan RK sama variatif (sama banyak): dua di RD dan dua di RK.

(23) [a], [o], dan [ə]

$\begin{array}{cll}\text { Glos } & \text { Berian } & \text { DP } \\ \text { bakar } & {[\text { bokar] }} & 11(\mathrm{RK}) \\ & {[\text { bakar] }} & 4,8,9(\mathrm{RD}), 16(\mathrm{RK}) \\ & {[\text { baka] }} & 2,3,5(\mathrm{RD}), 13(\mathrm{RK}) \\ & {[\text { bako] }} & 6(\mathrm{RD}) \\ & {[\text { bəka] }} & 10,12,17(\mathrm{RK}) \\ & {[\text { bokə] }} & 14(\mathrm{RK}) \\ & {[\text { boka }]} & 18(\mathrm{RK})\end{array}$

Vokal [a] terdapat pada DP $2-5,8$, dan 9 di RD dan di DP 10-13 dan 16-18 RK; Vokal [Ù] terdapat pada DP $14 \mathrm{RK}$; [o] terdapat pada DP 6 di RD.

Data (24) berikut menggambarkan bahwa vokal bahasa Melayu di RK juga lebih variatif daripada vokal di RD. Vokal [a] terdapat di semua DP di RD dan pada 5 DP di RK; [ə] terdapat pada DP 10, 17, dan 18 di RK; [] terdapat pada DP 12 di RK.

\section{(24) [a], [ə], []}

$\begin{array}{lll}\text { Glos } & \text { Berian } & \text { DP } \\ \text { hujan } & \text { [hujan] } & 4(\mathrm{RD}) \\ & \text { [ujan] } & 1-3,5-9(\mathrm{RD}), \\ & & 11,13,14-16(\mathrm{RK}) \\ & \text { [ujən] } & 10,17,18(\mathrm{RK}) \\ & \text { [ujn] } & 12(\mathrm{RK})\end{array}$

Data (26) berikut menggambarkan bahwa vokal bahasa Melayu di RK dan RD sama variatif. Vokal/diftong [i ${ }^{\mathrm{y} a}$ ] terdapat pada $1 \mathrm{DP}$ di RD; [e] hanya terdapat pada 2 DP di RK; [1] terdapat pada 8 di RD dan 4 DP di RK.

$\begin{array}{cll}\left.\text { (25) [i }{ }^{\mathrm{y} a}\right],[\mathrm{e}], & \text { dan [i] } & \\ \text { Glos } & \text { Berian } & \mathrm{DP} \\ \text { Angin } & \text { [ažìan] } & 8(\mathrm{RD}) \\ & \text { [ažen] } & 11,12(\mathrm{RK}) \\ & \text { [ažin] } & 1-7,9(\mathrm{RD}) \\ & & 10,14,15,16(\mathrm{RK})\end{array}$

Data variasi (26) berikut juga menggambarkan bahwa vokal bahasa Melayu di RK dan RD sama variatif. Vokal $[\mathrm{u}]$ terdapat pada 4 DP di RD dan 6 DP di RK; [o] terdapat pada 1 DP di RD dan 2 DP di RK; [ $\left.u^{w} a\right]$ terdapat pada 1 di RD Dapat dikatakan bahwa vokal di RK juga lebih variatif daripada di RD karena dasar vokal yang mendasarinya lebih banyak.

\begin{tabular}{|c|c|c|}
\hline \multicolumn{3}{|c|}{ 6) $[\mathrm{u}],[\mathrm{o}], \operatorname{dan}\left[\mathrm{u}^{\mathrm{w} a}\right]$} \\
\hline Glos & Berian & $\mathrm{DP}$ \\
\hline busuk & [busuk ] & $4,7(\mathrm{RD}), 13,15(\mathrm{RK})$ \\
\hline & [busuÀ] & $2,9(\mathrm{RD}), 10,16,17(\mathrm{RK})$ \\
\hline & [busok] & $12,18(\mathrm{RK})$ \\
\hline & [buso À] & $6(\mathrm{RD})$ \\
\hline & {$\left[\mathrm{bu}^{\grave{A}} \mathrm{Su}^{\grave{A}}\right]$} & $14(\mathrm{RK})$ \\
\hline & [busu'ak] & $1(\mathrm{RD})$ \\
\hline
\end{tabular}

Dari data (17) - (27) dapat diketahui bahwa vokal bahasa Melayu di RK dan di RD sama banyak. Vokal di RK enam, yaitu [a],[e], [ə], [u], [o], dan [i], sedangkan di RD juga tujuh, yaitu [a], [u], [o], [e], [i], [i $\left.{ }^{\mathrm{y} a}\right]$, dan [u $\left.\mathrm{u}^{\mathrm{w} a}\right]$.

\section{Simpulan}

Bahasa Melayu di beberapa wilayah Riau, baik di $\mathrm{RD}$ dan di RK memperlihatkan variasi. Analisis data pada 18 daerah pengamatan, 9 di RD dan 9 di RK, menunjukkan bahwa variasi bahasa Melayu di dua wilayah Riau itu ditandai oleh kesamaan etimon, kesamaan vokal, dan kebedaan vokal.

Realisasi bunyi vokal pada suku kata pertamabahasa Melayu di RK dan RD lima, yaitu [a],[ə], [u], [o], dan [i], sedangkan pada suku kedua semabilan, yaitu [a]; [o], [e]; [ə], [], [i $\left.{ }^{\mathrm{y} a}\right],[\mathrm{i}],[\mathrm{u}]$, dan [u'a]. Vokal pada suku kata kedua lebih banyak daripada vokal pada suku kata pertama. 
Realisasi bunyi vokal [a] pada suku kata pertama memperlihatkan kecenderungan dipakai di semua daerah pengamatan di RD, sedangkan di RK kecenderungannya hanya berada pada daerah pengamatan 13 (desa Dundur), daerah pengamatan 15 (desa Merawang), dan daerah pengamatan 16 (desa Pulau Laut). Pada suku kata kedua realisasi bunyi vokal itu juga memperlihatkan kecenderungan dipakai di semua daerah pengamatan di RD, sedangkan di RK kecenderungannya tidak pada semua daerah pengamatan. Daerah pengamatan yang tidak cenderung menggunakan bunyi vokal itu adalah daerah pengamatan 17 (desa Karas) dan daerah pengamatan 18 (desa Sedanau Timur).

Realisasi bunyivokal [i] pada suku kata pertama memperlihatkan kecenderungan dipakai di hampir semua daerah pengamatan baik di RD maupun RK, kecuali daerah 10 dan 13 . Sementara itu, pada suku kata kedua juga memperlihatkan kecenderungan dipakai di semua daerah pengamatan di RD dan di RK. Namun, ada daerah yang memperlihatkan kecenderungannya lebih banyak memakai vokal itu, yaitu di daerah pengamatan 7 (desa Pangkalan Indarung), daerah pengamatan 8, (desa Sukaping) di RD, dan di daerah pengamatan 17 (desa Karas) di RK.

Realisasi bunyi vokal [u] pada suku kata pertama memperlihatkan kecenderungan dipakai pada semua daerah pengamatan baik di RD maupun di RK. Sementara itu, realisasi bunyi vokal itu pada suku kata kedua juga memperlihatkan kecenderungan dipakai pada semua daerah $\mathrm{RK}$, tetapi ada daerah yang tidak cenderung memakai bunyi vocal itu, yaitu daerah 14 (desa Mantang Lama), daerah 16 (desa Pulau Laut), dan daerah 18 (desa Sedanau Timur).

Realisasi bunyi vokal [o] pada suku kata pertama memperlihatkan kecenderungan dipakai di RD. Hanya satu daerah di RD yang tidak memakai bunyi vokal itu, yaitu daerah 9 (desa Air Balui). Sementara itu, di RK realisasi bunyi vokal itu tidak terdapat pada daerah 14 (desa Matang Lama) dan daerah 15 (desa Merawang). Bunyi itu cenderung digunakan di daerah 1, desa Bangkinang, daerah 4, desa Pulau Godang, daerah 7 (desa Pangkalan Indarung) di RD, dan di daerah 18 (desa Sedanau Timur) RK. Pada suku kata kedua realisasi bunyi vokal itu cenderung dipakai pada daerah pengamatan di daerah 1 (Bangkinang), daerah 9 (desa Air Balui) RD, daerah 14 (desa Mantang Lama), dan daerah 18 (desa Sedanau Timur) di RK.

Realisasi bunyi vokal [] hanya pada suku kata kedua. Realisasi bunyi vokal itu hanya terdapat di RK, yaitu di daerah 12 (desa Ceruk) dan 13 (desa Dundur).

Realisasi bunyi vokal [e] cenderung terdapat di RK. Realisasi bunyi vokal itu dipakai di enam daerah pengamatan di RK dan empat daerah pengamatan di RD. Kerena data terbatas, tidak dapat ditentukan daerah mana yang cenderung memakai bunyi vokal itu. Sementara itu, pada suku kata kedua realisasi bunyi vokal itu dipakai di enam daerah pengamatan di RK dan enam daerah pengamatan di RD. Daerah yang cenderung memakai bunyi itu adalah daerah 1 (desa Bangkinang), daerah 3 (desa Pendalian), daerah 5 (desa Sukadamai), daerah 8 (desa Sukaping) di RD, dan daerah 14 (desa Mantang Lama) RK.

Realisasi bunyi vokal [ə] pada suku kata pertama cenderung terdapat di RK. Realisasi bunyi vokal itu dipakai di empat daerah pengamatan di RD dan di semua daerah pengamatan di RK. Di RD bunyi vokal itu cenderung digunakan di daerah 9, desa Air Balui dan daerah pengamatan di RK yang lebih banyak memakai bunyi itu adalah daerah 10 (desa Pecong) daerah 14 (desa Mantang Lama), dan daerah 17 (desa Karas). Hal seperti itu terlihat pula pada suku kata kedua. Berdasarkan data, dapat dikatakan bahwa di RD tidak terlihat daerah yang cenderung menggunakan bunyi itu. Sebaliknya, di RK daerah yang cenderung memakai bunyi vokal itu juga daerah 14 dan 17.

Realisasi bunyi vokal(diftong)[ìa]hanya terdapt pada suku kata kedua. Realisasi bunyi vokal itu hanya adadi DP8 di RD. Demikian pula [uwa] hanya terdapat di RD DP 1.

Data glos yang memiliki perbedaan realisasi bunyi vokal membuktikan bahwa bahasa Melayu di RK cenderung lebih variatif(lebih banyak vokal) pada suku kata pertama. Sementara itu, pada vokal suku kata kedua bahasa Melayu di RK juga cenderung lebih variatif daripada bahasa Melayu di RD. 
Di RD terlihat realisasi vokal pengaruh bahasa Minangkabau, khususnya terkait dengan vokal rangkap (diftong).

Jika ditinjau dari teori gelombang, daerah RK dapat ditafsirkan sebagai pusat penyebaran dan inovasi bahasa Melayu, sedangkan daerah RK dapat ditafsirkan daerah sebarannya karena, berdasarkan data, bahasa vokal Melayu RK lebih variatif daripada bahasa Melayu di RD.

\section{Daftar Pustaka}

Adelar, K. Alexander. 1994. Bahasa Melayik Purba Rekonstruksi dari Fonologi dan Sebagian Leksikon dan Morfologi. Jakarta: RUL.

Blust, Robert. 1981. "Rekonstruksi Bahsa MelayuJawa Purba" dalam Telaah Komparatif Bahasa Nusantara Barat: Kumpula Karya R.A. Blust oleh Bambang Kaswanti Purwo dan james T. Collis (Editor). Jakarta: Jambatan

Blust, Robert. 1981. "Suatu Ciri Fonologi Sejarah Bahasa Melayu yang Diabadikan" dalam Telaah Komparatif Bahasa Nusantara Barat: Kumpula Karya R.A. Blust oleh Bambang Kaswanti Purwo dan james T. Collis (Editor). Jakarta: Jambatan

Blust, Robert. 1988. "Malay Hisorical Linguistics: A Progres Report" dalam Rekonstruksi dan Cabang-Cabang Bahasa Melayu Induk oleh Moh. Thani Ahmad dan Zaini Mohamed Zein. Kuala Lumpur: Dewan Bahasa dan Pustaka.

Collins, James T. 1985. "Dialek Melayu di Kalimantan dan di Bangka: Misan dan Mindoan?" dalam Pelba 8. Jakarta: Unika Atma Jaya.

Collins, James T. 1986. Antologi Kajian Dialek Melayu. Kuala Lumpur: Dewan Bahasa dan Pustaka.

Dahlan, Saidat. 1976. "Bahasa dan Dialek Melayu Kabupaten Kampar Bagian Timur”. Jakarta: Pusat Pembinaan dan Pengembangan Bahasa.

Dahlan, Saidat. 1977. 'Hubungan Bahasa dan Dialek Melayu Kabupaten Kampar Bagian Timur dengan Bahasa di Daerah Bekas Kerajaan Siak". Jakarta: Pusat Pembinaan dan Pengembangan Bahasa.
Dahlan, Saidat.1989. Geografi Dialek Bahasa melayu Riau Kepulauan. Jakarta: Pusat Pembinaan dan Pengembangan Bahasa.

Fernadez, Inyo Yos. 1995. Relasi Historis Kekerabatan Bahasa Flores Kajian Linguistik Historis Komparatif Terhadap Sembian Bahasa di Flores. Flores: Nusa Indah.

Husin, Omar Amin. 1962. Sejarah Bangsa dan Bahasa Melayu. Kuala Lumpur: Dewan Bahasa dan Pustaka.

Hock, Hans Hnedrich.1986. Principles of Historical Linguistics. Berlin; New York; Amsterdam: Mouton de Gruyter

Keraf, Goris. 1984. Linguistik Bandingan Historis. Jakarta: PT Gramedia.

Lauder, Multamia R.M.T. 1998. "Usaha Melacak Bahasa Nusantara" dalam Pelba 12. Jakarta: Unika Atma Jaya.

Lauder, Multamia R.M.T. 2001. "Perkembangan Kajian Dialektologi di Indonesia" dalamPelba 15. Jakarta: Unika Atma Jaya.

Lauder, Multamia R.M.T. dan Ayatrohaedi.2005. "The Distribution of Austronesian and NonAustronesia Languages in Indonesia: Evidence and Issues". Papaer Delivered et The Internations and The Etnogenesis of The People in The Indonesian Archipelago, Solo 28 June1 July.

Mahsun. 1995. Dialektologi Diakronis Sebuah Pengantar. Yoyakarta: Gajah Mada University Press.

Nothofer, Bernard. 1975. The Reconstruction of Prot-Malay-Javanic. The Hague: Nijhoff.

Nothofer, Bernard. 1988. "A Discussion of Two Austronesian Subgroups: Proto-Malay and Proto-Malayic" dalam Rekonstruksi dan Cabang-Cabang Bahasa Melayu Induk oleh Moh. Thani Ahmad dan Zaini Mohamed Zein. Kuala Lumpur: Dewan Bahasa dan Pustaka.

Nothofer, Bernard. 1995. "Dialek Melayu di Kalimantan dan Bangka: Misan atau Mindoan" dalam Pelba 8. Jakarta: Unika Atma Jaya. 
Oglobin, A.K. 2000. "Evolusi Bahasa Kelompok Melayu-Jawa dalam Sorotan" dalam Pelba13. Jakarta: Unika Atma Jaya.

Omar, Amah Hj. 1991. Bahasa Melayu Abad ke16 Suatu Analisis Berdasarkan Teks Melayu. Kuala Lumpur: Dewan Bahasa dan Pustaka.

Robins, R.H. 1989/1992. Linguistik Umum: sebuah Pengantar. Terjemahan General Linguistics oleh S. Djajanegara. Yogyaakarta: Kanisius.
Schendel, Herbert. 1998. Historical Linguistcs. New York: Oxford University Press.

Summer Institut Linguistics. 2001. Languages of Indonesia. Jakarta: SIL International Indonesia Branch.

Tadmor, Uri. 2000. "Rekonstruksi Aksen Kata Bahasa Melayu" dalam Pelba13. Jakarta: Unika Atma Jaya. 